\title{
RELACJE MIĘDZY NASTĘPUJĄCYMI PO SOBIE TEORIAMI A SPOSOBY ODPOWIEDZI REALIZMU NAUKOWEGO NA ZARZUT PESYMISTYCZNEJ INDUKCJI
}

\begin{abstract}
Streszczenie. Artykuł nawiązuje do dyskusji wokół uzgodnienia realizmu naukowego z argumentem pesymistycznej indukcji (PI) i jest próbą jej rozwinięcia. Przedstawia propozycję dodatkowej argumentacji na rzecz realizmu naukowego, odwołującą się do pominiętej w realizmie strukturalnym i semirealizmie relacji korespondencji między następującymi po sobie teoriami. Pokazuje, że choć sposób argumentowania przyjęty w dotychczasowej dyskusji, opierający się na strategii divide et impera, trafnie odnosi się do przypadków zmiany teorii podobnych, do zastąpienia teorii optycznej Fresnela teorią elektromagnetyczną światła, to nie jest odpowiedni dla przypadków zmiany teorii, w których poprzedniczka i następczyni pozostają w relacji korespondencji. Rozwiązanie Worralla pomija istotne przesłanki, jakie z tej relacji wynikają dla rozumienia ciągłości teoretycznej. Uwzględnienie specyficznej różnicy zakresu zjawisk w następujących po sobie teoriach, które łączy relacja korespondencji, pozwoliło wskazać inny rodzaj ciągłości między teoriami i sformułować dodatkowe uzasadnienie dla realistycznego stanowiska wobec tego typu zmiany teorii. Wykazano, że w przypadku relacji korespondencji aproksymacyjna prawdziwość teorii i jej ciągłość mają inny charakter niż przyjmowany w strategii divide et impera, gdyż opierają się na innej relacji między następującymi po sobie teoriami. Odwołanie się do ograniczonego zakresu poprzedniczki i jej „lokalnego” względem następczyni charakteru pozwoliło uniknąć niektórych zarzutów, wysuwanych przeciwko argumentom na rzecz realizmu naukowego, odwołujących się do relacji korespondencji. W świetle przeprowadzonych rozważań teza, że zmiana dojrzałych teorii, odnoszących sukces, przeczy ich aproksymacyjnej prawdziwości, nie znajduje właściwego odniesienia do przypadków zmiany teorii, w wyniku której poprzedniczkę i następczynię łączy relacja korespondencji. Przedstawiona argumentacja uchyla zarzut PI w stosunku do tego rodzaju zmiany teorii i nie narzuca niektórych ograniczeń realizmu naukowego wynikających z realizmu strukturalnego.
\end{abstract}

Słowa kluczowe: realizm naukowy; realizm strukturalny; zmiana teorii; aproksymacyjna prawdziwość teorii; ciągłość teorii

1. Wstęp. 2. Realizm strukturalny i semirealizm jako odpowiedzi na argument pesymistycznej indukcji. 3. Graniczna zbieżność równań następujących po sobie teorii i zakres zjawisk, jakie one reprezentują. 4. Relacja korespondencji i ciągłość między następującymi po sobie teoriami.

5. Zakończenie. 


\section{WSTĘP}

Współczesna dyskusja pomiędzy realizmem i antyrealizmem naukowym dotyczy w dużej mierze prób uzgodnienia realizmu naukowego $\mathrm{z}$ historycznymi faktami zmiany teorii w nauce. Za główny argument na rzecz realizmu naukowego uznawany jest - wysunięty przez Hilarego Putnama - argument z braku cudów (NMA - No Miracles Argument). Putnam uznaje, że sukces teorii naukowej jest najlepszym świadectwem jej prawdziwości. Jak twierdzi, „realizm jest jedyną filozofią, która nie czyni sukcesu nauki cudem" (Putnam 1975, 73). Najważniejszym kontrargumentem dla NMA jest argument pesymistycznej indukcji (PI), odwołujący się do faktów radykalnej zmiany teorii w nauce. Głosi on, że skoro przeszłe teorie, które odnosiły sukces, okazywały się wraz z rozwojem nauki fałszywe, to także nasze obecne najlepsze teorie odnoszące sukces, mogą okazać się w przyszłości fałszywe ${ }^{1}$. Sukces teorii nie jest argumentem na rzecz jej prawdziwości lub nawet jej aproksymacyjnej prawdziwości². Uzgodnienie radykalnej zmiany teorii w nauce $z$ argumentem NMA stało się (i wciąż pozostaje) wyzwaniem dla stanowiska realizmu naukowego ${ }^{3}$.

Najważniejszych rozwiązań w tej kwestii dostarczają takie stanowiska, jak realizm strukturalny Johna Worralla (Worrall 2018, 145-175) i stanowiący jego rozwinięcie semirealizm Anjana Chakravarttiego (Chakravartty 1998, 391-408). Stanowiska te odwołują się do idei, że prawdziwe są nie tyle całe teorie, co raczej ich części

1 Trwa dyskusja, czy można w ten sam spsosób traktować przeszłe i obecne teorie, co jest założeniem argumentu PI. Por. Park 2017, 63-76 oraz Vickers 2017, 3221-3232.

2 Jedna z podstawowych tez realizmu naukowego głosi, że prawdziwość teorii naukowych należy rozumieć w znaczeniu korespondencyjnym. Por. Boyd 1983, 45-90.

3 Artykuł ten nawiązuje do artykułu: Buczkowska 2020, w którym przedstawione jest obszerne omówienie obu argumentów. 
bezpośrednio związane z sukcesem ${ }^{4}$. Pozwala to częściowo uchylić zarzut PI. W tym kontekście często rozważana jest teoria Fresnela, która odniosła sukces, choć postulowała, jak się z czasem okazało, nieistniejący eter. $W$ myśl wspomnianych stanowisk eter nie był jednak związany z tą częścią teorii, dzięki której odniosła ona sukces.

J. Worrall przyjmuje przejście od teorii Fresnela do teorii Maxwella jako modelowy przykład zmiany teorii w nauce i na jego podstawie wyprowadza wnioski, które uogólnia na inne przypadki zmiany teorii. Jak zauważa sam Worrall, przypadek przejścia od teorii światła Fresnela do teorii Maxwella nie jest reprezentatywny dla innych przypadków zmiany teorii. Równania Fresnela pojawiają się w teorii Maxwella (po odpowiedniej interpretacji) w takiej samej matematycznej formie. Znacznie częściej jednak równania wcześniejszej teorii stanowią jedynie graniczne przypadki odpowiednich równań teorii późniejszej, zasadniczo różnych od równań poprzedniczki (Worrall 2018, 170-171). Taka zależność pomiędzy teoriami jest nazywana „relacją korespondencji”. Worrall konstatuje, że, gdy pomiędzy poprzedniczką i następczynią zachodzi relacja korespondencji, zmiana teorii przebiega według innego schematu niż przejście od teorii Fresnela do teorii Maxwella, gdzie równania poprzedniczki są zachowane w jej następczyni w niezmienionej formie. Nie wyprowadza jednak z relacji korespondencji dodatkowej argumentacji. Twierdzi, że relacja korespondencji dowodzi jedynie słuszności ograniczonej wersji realizmu, jaką jest realizm strukturalny (Worrall 2018, 171-174). Kwestionuje natomiast, zgodnie ze stanowiskiem antyrealistycznym, łączenie z tą relacją argumentów na rzecz innego rodzaju ciągłości między następującymi po sobie teoriami niż ciągłość niezinterpretowanych równań matematycznych. Jego rozwiązanie prowadzi do znacznego ograniczenia stanowiska realistycznego.

4 Ze względu na liczne omówienia zarówno tekstów Johna Worralla, jak i Anjana Chakravarttiego, zamieszczam tylko konieczne odniesienia do ich treści. 
Artykuł ma na celu pokazać, że różnica pomiędzy zmianą teorii według obu schematów jest istotna i polega na odmienności relacji pomiędzy następującymi po sobie teoriami. Ta różnica relacji łączy się z tym, że w obu typach zmiany teorii inaczej jest rozumiana aproksymacyjna prawdziwość poprzedniczki w świetle następczyni, inaczej też przejawia się ciągłość pomiędzy nimi. Rodzi to potrzebę odmiennego uzasadnienia realistycznego stanowiska w obu przypadkach. Niniejszy tekst wykazuje, że relacja korespondencji pozwala na dodatkowe uzasadnienie realistycznej interpretacji zmiany teorii, które wykracza poza propozycję realizmu strukturalnego. Przedstawione w pracy argumenty pozwalają na uchylenie argumentu PI w stosunku do takiego rodzaju przypadków zmiany teorii. Jak zostanie pokazane, w przypadku relacji korespondencji między teoriami nie następuje odrzucenie poprzedniczki ani jej elementów jako fałszywych. Teoria pozostaje aproksymacyjnie prawdziwa w zakresie zjawisk granicznych nowej teorii. Stanowi to dodatkową argumentację na rzecz realistycznej interpretacji zmiany teorii w nauce.

\section{REALIZM STRUKTURALNY I SEMIREALIZM JAKO ODPOWIEDZI NA ARGUMENT PESYMISTYCZNEJ INDUKCJI}

Hilary Putnam w 1975 roku sformułował tezę, że najlepszym potwierdzeniem realizmu naukowego jest niewiarygodny wprost sukces nauki. Jego argument, zwany argumentem z braku cudów, łączący sukces teorii naukowej z jej aproksymacyjną prawdziwością, jest wciąż najbardziej znaczącym argumentem na rzecz realizmu naukowego. Larry Laudan podważył ten argument, wskazując w historii nauki liczne przykłady teorii, które, pomimo że odnosiły sukces, były w wyniku zmiany teorii uznawane za fałszywe, a postulowane przez nie nieobserwowalne obiekty (jak np. flogiston czy eter) okazywały się nierealne (Laudan 2018, 29-65, 35-47). Zdaniem Laudana fakty radykalnej zmiany teorii podważają argument $\mathrm{z}$ sukcesu nauki oraz główne tezy realizmu naukowego. Sukces teorii nie stanowi gwarancji 
jej aproksymacyjnej prawdziwości i istnienia postulowanych przez nią obiektów.

Stanowisko Laudana wpisuje się w podstawowy sposób argumentacji przeciwko realizmowi naukowemu, jakim jest bardziej ogólny, odwołujący się do faktów radykalnej zmiany teorii, argument pesymistycznej indukcji (PI). Głosi on, że jeśli przeszłe teorie, które w swoim czasie odnosiły sukces, okazywały się wraz z rozwojem nauki fałszywe, to nawet nasze najlepsze współczesne teorie odnoszące sukces, mogą okazać się w przyszłości fałszywe (Rodzeń 2006, 97-110). Problem realistycznej interpretacji faktu zmiany teorii stał się więc podstawowym wyzwaniem dla realizmu naukowego.

Krytyka realizmu naukowego pod wpływem argumentu PI doprowadziła do zawężenia zbioru teorii naukowych, które bierze się pod uwagę $\mathrm{w}$ dyskusji nad realizmem naukowym. Tezy realizmu odnoszą się, zdaniem J. Worralla (Worrall 2018, 162-163), S. Psillosa (Psillos 1999, 108) oraz innych współczesnych przedstawicieli realizmu naukowego tylko do „dojrzałych teorii”, to znaczy takich, które odniosły sukces w przewidywaniu zjawisk nowej kategorii, czyli sukces predykcyjny ${ }^{5}$. Ograniczenia te jednak nie wyeliminowały wszystkich wskazanych przez Laudana przypadków teorii, które osiągnęły sukces predykcyjny i zostały z czasem zakwestionowane. Najczęściej dyskutowanym przykładem jest przypadek optycznej teorii światła Fresnela (wyjaśniającej światło jako drgania mechanicznego eteru), która odniosła sukces predykcyjny, pomimo że istnienie eteru zostało wraz z rozwojem nauki zanegowane.

Dla obrony realizmu przed zarzutem PI przyjmowana jest często strategia divide et impera, opierająca się na założeniu, że elementy teorii związane bezpośrednio z jej sukcesem są prawdziwe lub aproksymacyjnie prawdziwe, i ze względu na swoją aproksymacyjną prawdziwość są zachowywane w kolejnych teoriach (Vickers 2017, 3221-3232, Park 2017, 63-76). Warunek ten zapewnia to, że nauki

5 Dyskutowana jest sama zasadność argumentu PI w stosunku do współczesnych teorii. 
mają charakter kumulatywny, gdyż nowe teorie przejmują prawdziwe części swoich poprzedniczek, natomiast części wcześniejszej teorii, które nie znajdują kontynuacji w następczyni, są odrzucane jako fałszywe (Lyons 2006, 537-560). Zatem nie całe teorie, a tylko ich fragmenty mają realistyczną interpretację.

Jedną z podstawowych trudności tej strategii jest fakt, że ocena, które elementy teorii odnoszącej sukces są aproksymacyjnie prawdziwe, następuje dopiero w świetle nowej teorii. Są to bowiem te fragmenty, które zostały zachowane w następczyni. Podejście takie relatywizuje prawdziwość fragmentów jednej teorii do ich zachowania w innej, kolejnej teorii, co odbiega od przyjmowanej w stanowiskach realistycznych korespondencyjnej teorii prawdy. Jest to jednak najczęściej przyjmowany sposób uzgodnienia argumentu NMA z argumentem pesymistycznej indukcji.

Jedną z ważniejszych odpowiedzi ze stanowiska realizmu naukowego na wyzwanie radykalnej zmiany teorii jest zaproponowany przez J. Worralla realizm strukturalny. Jego rozszerzenia o aspekt nieobserwowanych obiektów dostarcza semirealizm A. Chakravarttiego. Oba te stanowiska, nawiązujące do strukturalistycznego ujęcia teorii naukowych, stały się ważnym punktem odniesienia dla aktualnej dyskusji wokół zagadnienia realizmu naukowego.

J. Worrall broni związku sukcesu predykcyjnego teorii z jej aproksymacyjną prawdziwością, zgodnie z opisaną wyżej strategią. Przyjmuje, że elementy teorii, odpowiedzialne za jej sukces predykcyjny, jako aproksymacyjnie prawdziwe, powinny być zachowane w kolejnych, następujących po sobie teoriach. Zachowanie elementów starej teorii w nowej jest argumentem na rzecz aproksymacyjnej prawdziwości tej pierwszej w zakresie zachowanych części. Zapewnia to częściową ciągłość teoretyczną pomiędzy następującymi po sobie teoriami.

Jako modelowy przykład zmiany teorii Worrall rozważa przypadek przejścia w optyce pomiędzy teorią Fresnela i teorią elektromagnetyczną światła. Zgodnie $\mathrm{z}$ teorią Fresnela światło jest falą 
poprzeczną, rozchodzącą się jako drgania eteru, rozumianego jako ciągły, sprężysty ośrodek mechaniczny. Teoria ta odniosła sukces empiryczny i predykcyjny, pomimo że zakładała istnienie eteru, które zostało w wyniku rozwoju nauki zanegowane. Teorię Fresnela zastąpiła teoria Maxwella, zgodnie z którą światło jest falą elektromagnetyczną, rozchodząca się w eterze. Choć, jak pisze Worrall, Maxwell „walczył mężnie, aby wyjaśnić pole elektromagnetyczne w kategoriach jakiegoś fundamentalnego mechanicznego medium. Podejmowane przez niego próby zakończyły się jednak fiaskiem i z czasem uznano pole elektromagnetyczne za pierwotne" (Worrall 2018, 155). Natura światła według każdej z teorii była inna, jednak matematyczne równania, sformułowane przez Fresnela, zostały w tej samej formie matematycznej wyprowadzone $\mathrm{z}$ teorii elektromagnetyzmu Maxwella.

Ta zgodność równań obu teorii jest dla Worralla argumentem na rzecz pewnej formy realizmu naukowego. Twierdzi on, podobnie jak Poincaré, że formalizm matematyczny pozwala na prawdziwe przewidywanie zjawisk, gdyż odzwierciedla realne, nieobserwowalne struktury rzeczywistości. Dlatego pozostaje niezmieniony przy przejściu od jednej dojrzałej teorii do drugiej, pomimo że jego interpretacja ulega znaczącej zmianie. Jeśli zatem ograniczymy się do poziomu równań matematycznych, to na poziomie formalnym zachodzi zgodność pomiędzy teorią Fresnela i teorią Maxwella (Worrall 2018, 169). Różnica pomiędzy wcześniejszą i późniejszą teorią dotyczyła ontologicznej interpretacji tych równań, która nie miała wpływu na sukces predykcyjny teorii Fresnela i nie zagrażała aproksymacyjnej prawdziwości jego równań.

W przypadku radykalnej zmiany dojrzałych teorii zostaje zachowany, według Worralla, istotny element treści teoretycznej, którym są matematyczne równania teorii. Nie tylko treść empiryczna poprzedniczki, wbrew stanowisku Basa van Fraassena (Fraassen 1980, 40), ale i jej formalny składnik teoretyczny jest dziedziczony przez następczynię. Dzieje się tak, ponieważ, zdaniem Worralla, 
matematyczne równania dojrzałych teorii naukowych odzwierciedlają realne struktury rzeczywistości, które tworzą relacje pomiędzy własnościami nieobserwowalnych obiektów. Zmiana teorii nie podważa samych relacji przyczynowych i odzwierciedlających je równań, choć może podważyć ontologię, w jakiej je interpretowano. Kumulacja wiedzy, jaka ma miejsce w wypadku zastąpienia teorii Fresnela teorią Maxwella, ogranicza się do odtworzenia części równań matematycznych starej teorii w nowej.

Realizm strukturalny Worralla jest ograniczoną wersją realizmu naukowego ${ }^{6}$. Realne są jedynie nieobserwowalne struktury rzeczywistości reprezentowane przez formalizm matematyczny teorii, odzwierciedlający obserwowane empirycznie relacje przyczynowe. Jest to jedyna wiedza o rzeczywistości, jakiej mogą nam dostarczyć teorie naukowe. Całkowicie niepoznawalne pozostają natomiast składniki rzeczywistości, takie jak postulowane przez teorie nieobserwowane obiekty i ich własności. Natura zjawisk jest niepoznawalna. Realny sens ma tylko struktura relacyjna zjawisk odzwierciedlona w abstrakcyjnych strukturach matematycznych. Ciągłość teorii zapewniają niezinterpretowane równania matematyczne, podczas gdy postulaty ontologiczne teorii nie mają realistycznej interpretacji i mogą zmieniać się w różnych teoriach.

A. Chakravartty wykazuje, że przyjęcie realizmu strukturalnego ma jednak określone konsekwencje odnośnie do istnienia i własności obiektów teoretycznych. „Wiedza o strukturach implikuje wiedzę zarówno o istnieniu bytów spełniających te struktury, jak i o ich niektórych właściwościach detekcyjnych" (Chakravartty 1998, 399). Twierdzi, że nie można odmówić realności przedmiotom charakteryzowanym przez własności detekcyjne, które leżą u podstaw obserwowanych pośrednio i bezpośrednio związków przyczynowych,

6 Wersją podstawową w tym kontekście jest realizm konwergentny, sformułowany przez R. Boyda, którego ograniczonymi wersjami są bardziej współczesne stanowiska realizmu naukowego. 
ujmowanych w równaniach matematycznych. Charakterystyka ta nie musi być wyczerpująca, ale własności te wskazują na ich realne nośniki. Własności detekcyjne są powiązane z doświadczeniem i służą do interpretacji równań matematycznych i ich odniesienia do zjawisk. Teoria wyposaża przedmioty zidentyfikowane przez własności detekcyjne w dodatkowe cechy, tzw. własności pomocnicze, które odgrywają rolę heurystyczną w teoretycznym wyjaśnianiu zjawisk. Własności pomocnicze nie mogą być traktowane realistycznie. Natomiast własności detekcyjne, obok równań matematycznych, stanowią wiedzę na temat obiektów generujących struktury relacyjne, wskazywane przez Worralla. Własności te są zachowane przez obiekty nowej teorii, generujące struktury opisywane w jej równaniach, choć przypisywane im własności pomocnicze mogą się zmieniać.

Oba stanowiska nakładają istotne ograniczenia na realistyczne rozumienie teorii naukowych. Worrall uznaje, że prawdziwa treść teorii naukowych ogranicza się do równań matematycznych. Chakravartty rozszerza ją o własności detekcyjne, które jednak nie wyczerpują charakterystyki postulowanych przez teorie przedmiotów.

Inną ważną trudnością realizmu strukturalnego jest to, że nie mówi on nic o obecnych teoriach. Aproksymacyjnie prawdziwe elementy teorii poznajemy dopiero z perspektywy jej następczyni, są to bowiem te równania teorii, które zostają zachowane (w całości lub jako graniczne przypadki) przy zmianie teorii. Nie jest to jednak cały aparat matematyczny teorii. Na przykład w teorii Fresnela obok równań, które stały się częścią teorii Maxwella, było wiele matematycznych sformułowań praw odnośnie do samego eteru. Maxwell również przyjmował istnienie eteru, choć wyposażał go w nieco inne własności niż Fresnel. Wszystkie te prawa wraz z ich matematycznymi sformułowaniami zostały odrzucone wskutek odrzucenia teorii eteru. Jednak z perspektywy każdej z tych teorii trudno było powiedzieć, które jej elementy są związane z sukcesem. Staje się to widoczne dopiero z perspektywy kolejnych teorii. Realizm strukturalny nie określa warunków, które w ramach danej teorii 
identyfikowałyby te elementy jej formalizmu matematycznego, które są związane bezpośrednio z jej sukcesem. Zdaniem Chakravartty'ego semirealizm oferuje takie kryterium. Jest nim ograniczenie się do równań opisujących związki między własnościami detekcyjnymi.

Jak zostanie dalej pokazane, pewne ograniczenia są konsekwencją przyjęcia przypadku przejścia od teorii światła Fresnela do teorii elektromagnetycznej jako reprezentatywnego dla wszystkich przypadków zmiany dojrzałych teorii. To, co Worrall wskazuje jako istotne dla tego przypadku, to zachowanie równań poprzedniczki w tej samej formie w następującej po niej teorii. Jak zauważa sam Worrall: „W dużo częściej spotykanym schemacie stare równania pojawiają się jako przypadki graniczne nowych - to jest stare i nowe równania są, ściśle rzecz biorąc sprzeczne, lecz nowe dążą do starych tak, jak jakaś wielkość dąży do jakiejś granicy" (Worrall 2018, 171). Worrall konstatuje jedynie ten fakt i uogólnia wnioski wyprowadzone dla jednego, jak określa, „schematu” zmiany teorii na inny. Nie uznaje jednak, że relacja korespondencji może wnosić coś więcej do jego argumentacji i dostarczyć podstawy do zachowania realistycznego stanowiska w szerszym zakresie, niż tylko w odniesieniu do równań matematycznych.

Zostanie więc pokazane, że rodzaj ciągłości teorii w obu tych schematach jest inny i powinien być rozpatrywany w odwołaniu do innych relacji pomiędzy następującymi po sobie teoriami. Dla uzgodnienia przypadku przejścia od teorii Fresnela do teorii Maxwella $\mathrm{z}$ realizmem naukowym można odwołać się do strategii divide et impera, która zakłada zachowanie w nowej teorii elementów starej. Jednak gdy następujące po sobie teorie łączy zależność tego rodzaju, że równania starszej teorii są granicznymi przypadkami równań jej następczyni (określana jako relacja korespondencji), ciągłość teorii jest podważana na rożne sposoby. $\mathrm{W}$ dalszej części zostanie także pokazane, że w przypadku, gdy następujące po sobie teorie łączy relacja korespondencji, potrzebne jest inne wyjaśnienie zachowania ciągłości pomiędzy następującymi teoriami. W innym sensie rozumiana te $\dot{z}$ 
jest aproksymacyjna prawdziwość teorii i kumulatywny charakter nauki. Odwołanie się do relacji korespondencji pozwoli na uchylenie niektórych ograniczeń, jakie na realizm naukowy nakładają realizm strukturalny i semirealim, odwołujące się w swej argumentacji do strategii divide et impera.

Stanowiska Worralla i Chakravartty'ego znajdują swoje wielokrotne i szerokie omówienia w literaturze przedmiotu, dlatego dalej będą traktowane jako znane, przynajmniej w podstawowym zakresie (por. Kotowski 2014, 105-123).

Worrall, jak to zostało już wspomniane w kontekście obrony realizmu naukowego, traktuje jednakowo przypadki zmiany teorii, w których niektóre równania poprzedniczki są zachowane w następczyni w takiej samej formie (przejście od teorii Fresnela do teorii Maxwella) oraz przypadki, w których równania poprzedniczki stanowią graniczne przypadki równań następczyni, jak na przykład przejście od teorii ruchu Newtona do szczególnej teorii względności Einsteina (STW). Ten drugi rodzaj zależności równań następujących po sobie teorii będzie dalej określany „graniczną zbieżnością równań”. Realistyczna interpretacja zmiany teorii drugiego typu jest jednak kwestionowana z pozycji antyrealizmu naukowego. Podnoszona jest kwestia, że relacja korespondencji, polegająca na tym, że równania poprzedniczki są granicznymi przypadkami następczyni, nie stanowi podstawy do uznania ciągłości między następującymi po sobie niewspółmiernymi teoriami. Zostanie więc pokazane, że relacja korespondencji może stanowić uzasadnienie dla określonego sposobu rozumienia aproksymacyjnej prawdziwości zastępowanej teorii, kumulatywnego charakteru nauki i ciągłości między teoriami.

Fresnel przypisał światłu własność bycia falą poprzeczną i teoria Maxwella zachowuje tę własność światła. Formalizm matematycznych równań propagacji fali poprzecznej, zaproponowany przez Fresnela, odnosi się do wszystkich fal poprzecznych niezależnie od natury drgającego ośrodka. Równania Fresnela nie są granicznym przypadkiem równań Maxwella, lecz poddane reinterpretacji, stają 
się elementem nowej teorii. Uznanie falowości światła przez Fresnela było postępem $\mathrm{w}$ rozpoznawaniu natury światła $\mathrm{w}$ stosunku do korpuskularnej teorii światła Newtona. Teoria Fresnela uznawała, że światło rozchodzi się jak fala poprzeczna, co było odkryciem istotnej własności światła, zachowanej też w teorii Maxwella. Błędnie jednak Fresnel identyfikował światło jako falę mechanicznego eteru. Maxwell zidentyfikował światło jako falę elektromagnetyczną, rozchodzącą się w eterze. Choć przyjmował on istnienie eteru, to przypisanie światłu natury fal elektromagnetycznych było istotną zmianą w stosunku do teorii Fresnela.

Worrall wyjaśnia sukces teorii Fresnela i jego związek z aproksymacyjną prawdziwością tej teorii zgodnie ze strategią divide et impera. Część teorii Fresnela, odpowiedzialna za jej sukces predykcyjny, a mianowicie teza, że światło jest falą poprzeczną, została zachowana w nowej teorii jako jej istotny element. W tym przypadku aproksymacyjna prawdziwość teorii Fresnela, w świetle teorii Maxwella, oznacza zgodność części teorii Fresnela (równań opisujących odbicie i załamanie światła spolaryzowanego na granicy dwóch ośrodków) z teorią Maxwella. Jest to aproksymacyjna prawdziwość teorii $T_{1} \mathrm{w}$ sensie prawdziwości jej określonej części (częściowej prawdziwości $\mathrm{T}_{1}$ ) $\mathrm{w}$ świetle $\mathrm{T}_{2}$. Kumulacja wiedzy polega w takim przypadku na zachowaniu aproksymacyjnie prawdziwego elementu poprzedniczki $T_{1} w$ nowej teorii $T_{2}$ i następujących po niej teoriach. Pozostała część teorii, związana z eterem, nie miała związku z jej sukcesem predykcyjnym. Okazała się też z czasem fałszywa, kiedy Einstein odrzucił hipotezę eteru jako ośrodka rozchodzenia się fal elektromagnetycznych.

Inna jest sytuacja w przypadku przejścia od teorii Newtona do STW. Teoria Einsteina nie zachowuje żadnej części teorii Newtona jako obowiązującej dla całego zakresu ruchów opisywanych przez STW. Dlatego stosowanie strategii divide et impera do tego przypadku nie ma uzasadnienia. Równania Newtona są zasadniczo różne od równań STW, choć są formalnie zgodne z graniczną 
postacią odpowiednich równań STW. W tym przypadku zgodność $\mathrm{T}_{1} \mathrm{z}$ teorią $\mathrm{T}_{2}$ polega na zgodności niektórych równań $\mathrm{T}_{1} \mathrm{z}$ graniczną postacią równań teorii $T_{2}$. Worrall ogranicza ciągłość teoretyczną tylko do równań matematycznych i odrzuca korespondencję innych elementów obu teorii. W takim ujęciu aproksymacyjna prawdziwość teorii $\mathrm{T}_{1}$ opiera się na zgodności jej równań $\mathrm{z}$ graniczną postacią równań następującej po niej teorii $\mathrm{T}_{2}$. Rozumienie aproksymacyjnej prawdziwości w tym przypadku wymaga jednak dalszych wyjaśnień.

Ze względu na typ relacji łączącej następujące po sobie teorie można mówić o dwu istotnie różnych sposobach (schematach) zmiany teorii $\mathrm{w}$ nauce. $\mathrm{W}$ obu przypadkach mamy do czynienia $\mathrm{z}$ innym pojęciem aproksymacyjnej prawdziwości. W pierwszym przypadku jest to prawdziwość tylko części teorii, w drugim przypadku jest to przybliżona prawdziwość teorii w sensie granicznej zbieżności równań. Oba przypadki łączą się także z innym rodzajem wkładu starej teorii w rozwój wiedzy. Pierwszy polega na tym, że starsze teorie, choć w części fałszywe, odkrywają pewne uniwersalne własności zjawisk lub obiektów, które stają się częścią nowej teorii (zmiana teorii: Fresnel - Maxwell). Drugi polega na tym, że starsze teorie są aproksymacyjnie prawdziwe dla pewnej ograniczonej klasy zjawisk, stanowiących graniczne przypadki zastosowania nowszej teorii.

Podsumowując, analiza przypadków zmiany teorii, gdy następujące po sobie teorie łączy relacja granicznej zbieżności równań, wskazuje, że dla tych przypadków należy szukać innej drogi (niż dla przypadków zachowania części zastępowanej teorii w następczyni) uzgodnienia realizmu naukowego $\mathrm{z}$ argumentem PI. Uzgodnienie to powinno uwzględniać specyfikę relacji korespondencji.

\section{GRANICZNA ZBIEŻNOŚĆ RÓWNAŃ NASTĘPUJĄCYCH PO SOBIE TEORII I ZAKRES ZJAWISK, JAKIE ONE REPREZENTUJĄ}

Worrall odwołuje się do strukturalno-modelowego ujęcia empirycznych teorii naukowych, zgodnie z którym modele matematyczne 
reprezentują zjawiska, których struktury, według Newtona da Costy i Stevena Frencha, są izomorficzne z tymi modelami (Da Costa, French 1990, 249). Niektórzy autorzy przyjmują homomorfizm struktur modelu matematycznego i struktur rzeczywistości ${ }^{7}$. Struktura jest w tym kontekście rozumiana na wzór struktury matematycznej, której najprostszym przykładem jest zbiór abstrakcyjnych obiektów i relacji zachodzących pomiędzy nimi (Suppe 1989; Giere 2004, 747; 1988, 270). Worrall przyjmuje, że graniczna zbieżność równań odzwierciedla zbieżność struktur reprezentowanych przez obie teorie.

Pojawia się pytanie, czy w przypadku radykalnej zmiany teorii następujące po sobie teorie zawsze odnoszą się do tych samych zjawisk lub reprezentują te same struktury zjawisk? Czy teoria Newtona była nakierowana na wyjaśnienie tych samych przypadków ruchów, co np. STW? W przypadku granicznej zbieżności równań nowa teoria odnosi się na ogół do innego, szerszego zakresu zjawisk, niż jej poprzedniczka. Zakres ten obejmuje obok zjawisk typowych dla starej teorii zjawiska nowego typu, dla wyjaśnienia których stara teoria zawodziła.

Adekwatność teorii w odniesieniu do zjawisk polega, zdaniem van Fraassena, na tym, że struktury, które reprezentują zjawiska w kategoriach odpowiednich parametrów, „pasują" do modelu teoretycznego, np. są z nim izomorficzne (Fraassen 1997, 524). Teoria dostarcza modelu dla tej klasy zjawisk, które reprezentuje. Stosuje się do „wycinków” rzeczywistości, dla których stanowi model, a nie do "całego świata"8. Przyjmijmy za Sneedem- Stegmüllerem, że teoria odnosi się do zbioru zjawisk, które ma za zadanie wyjaśnić, czyli do „zbioru zamierzonych zastosowań". Zbiór ten jest zdefiniowany paradygmatycznie (przez przykłady). Teoria odnosi się do przypadków,

7 Pojawia się jednak problem, że w modelu matematycznym odwzorowywane są nie struktury rzeczywistości, lecz struktury matematycznego modelu danych. Wtedy model zatraca to, co reprezentuje. Por. Frigg 2006, 54.

8 W zwarty sposób omawia tę koncepcję Adam Grobler (Grobler 2008). 
które można uznać za podobne do przypadków paradygmatycznych (Grobler 2008, 182). Pojęcie „zamierzone zastosowania” uwzględnia fakt, że u podstaw sformułowania teorii leżą pewne zjawiska, które ona ma wyjaśniać i dla których dostarcza modelu matematycznego. $\mathrm{Na}$ przykład do zbioru zamierzonych zastosowań teorii Newtona należały ruchy podobne do ruchów planet i ciał makroskopowych w pobliżu powierzchni Ziemi. STW przyjęła szerszy zbiór zamierzonych zastosowań w stosunku do teorii Newtona, w którym centralne miejsce zajmują zjawiska związane $\mathrm{z}$ ruchem światła i ruchami $\mathrm{z}$ dużymi prędkościami, które stały się przypadkami paradygmatycznymi dla tej teorii. Ruchy z małymi prędkościami stanowią dla niej jedynie przypadki graniczne, które nie posiadają pełnej charakterystyki zjawisk paradygmatycznych. Wskazywanie granicznych przypadków wiąże się z paradygmatycznym sposobem definiowania zbioru zamierzonych zastosowań. Przypadki paradygmatyczne i bardzo do nich podobne określane są $\mathrm{w}$ tym podejściu, jako przypadki „centralne” dla danej teorii. Krótszy termin „zakres teorii” będzie w dalszej części pracy używany w sensie takim, jak termin „zakres zamierzonych zastosowań” i będzie się wiązał z opisanym powyżej „lokalnym” charakterem teorii naukowych. Pokazuje to, że teorie naukowe, wbrew przekonaniu ich twórców, nie są uniwersalne w pełnym stopniu. Są one „uniwersalne” w tym sensie, że obejmują cały zakres zjawisk znanych w czasie ich formulowania i obowiązywania.

W wypadku zmiany teorii, której poprzedniczkę i następczynię łączy relacja granicznej zbieżności równań (korespondencji), zbiory zamierzonych zastosowań obu teorii różnią się w taki sposób, że paradygmatyczne zjawiska starej teorii stają się granicznymi przypadkami nowej, natomiast paradygmatyczne przypadki nowej teorii nie należą do zbioru zamierzonych zastosowań poprzedniczki. Nowa teoria wyjaśnia szerszą klasę zjawisk i jest bardziej uniwersalna, gdyż obejmuje też zakres poprzedniczki.

Jeśli równania matematyczne teorii reprezentują struktury zjawisk, to następujące po sobie teorie, których równania się różnią, 
mogą reprezentować struktury różnych zbiorów zjawisk. Struktury reprezentowane w nowej teorii uwzględniają te relacje, które nie ujawniają się wyraźnie w równaniach wcześniejszej teorii. Dla zjawisk granicznych nowej teorii, które były zjawiskami centralnymi poprzedniczki, równania obu teorii są zbieżne, co oznacza, że dla tych zjawisk pewne relacje, właściwe i dominujące dla nowej teorii, nie odgrywają znaczącej roli. $Z$ perspektywy nowej teorii, na przykład STW, teoria Newtona opisywała aproksymacyjnie prawdziwie graniczne przypadki ruchu, reprezentując uproszczone struktury tego obszaru ruchów „pasujące” do ich detekcyjnych parametrów. Nie odzwierciedlała jednak wszystkich zależności, jakie przejawiaja się w paradygmatycznych dla STW przypadkach.

W stosunku do realizmu strukturalnego Worralla formułowano zarzut, że dopiero z perspektywy nowej teorii można rozpoznać, która część teorii odpowiada za jej sukces i jest aproksymacyjnie prawdziwa, gdyż zostanie ona zachowana w następczyni. Trudność ta w sytuacji granicznej zbieżności równań pojawia się w nieco łagodniejszej postaci. Choć nie można podać ograniczenia zakresu teorii, zanim nie zostaną odkryte zjawiska, dla których teoria się załamuje, to w zakresie zjawisk, w jakim odnosi ona sukces, jest też aproksymacyjnie prawdziwa. Nie można przewidzieć, dla jakich

9 Stanowisko Worralla i jego rozwinięcie w wersji ontologicznej realizmu strukturalnego rodzi trudności związane z wyjaśnieniem relacji struktury matematycznej do rzeczywistości. Struktura matematyczna teorii jest konfrontowana z modelem danych, co wymaga pewnej ontologicznej interpretacji teorii, aby było możliwe odniesienie jej do badanych zjawisk. Realizm strukturalny nie dostarcza takiej interpretacji, nie ma on narzędzi, aby rozstrzygnąć np. pomiędzy ontologiami różnych matematycznych sformułowań mechaniki kwantowej, a zatem określić, która z proponowanych struktur ma status realnej. Worrall odrzuca możliwość i potrzebę takiej interpretacji, jednak w takim kontekście realizm strukturalny zbliża się bardzo do empiryzmu konstruktywnego van Frassena lub nawet do instrumentalizmu (por. Becker Arenhart, Bueno 2015, 111-139). Celem tego artykułu jest jednak nie tyle analiza trudności realizmu strukturalnego, co pokazanie, że zmiana formalizmu matematycznego w wypadku zmiany teorii nie zawsze skutkuje fałszywością poprzedniczki. 
zjawisk, wykraczających poza zbiór zamierzonych zastosowań, teoria okaże się fałszywa, ale można powiedzieć, że dla zjawisk zbliżonych do paradygmatycznych jest aproksymacyjnie prawdziwa. Choć Newton traktował swoją teorię jako uniwersalną, to jednak jej równania miały reprezentować jemu znane ruchy i ruchy do nich podobne; takie stanowiły zakres jego teorii. W tym zakresie była ona aproksymacyjnie prawdziwa. Wyraźne efekty relatywistyczne leżą poza zbiorem zamierzonych zastosowań teorii Newtona i dla tych ruchów traci ona empiryczną zgodność ze swoimi przewidywaniami. Nie jest też w tym zakresie aproksymacyjnie prawdziwa lecz fałszywa.

Pod wpływem doświadczenia zbiór zamierzonych zastosowań teorii podlega ewolucji. Konstruowane są zarówno nowe zastosowania, jak i, w wypadku falsyfikacji, następuje usunięcie niektórych z nich. Jest on wraz z rozwojem teorii rozszerzany na kolejne zjawiska interpretowane jako podobne, a kryterium podobieństwa jest empiryczny sukces takich zastosowań. Zakres teorii zostaje ostatecznie ograniczony przez zastępującą ją teorię niejako od zewnątrz. Jednak już z perspektywy samej teorii „od wewnątrz" granice te się uwidaczniają. Brak sukcesu w wyjaśnianiu nowych zjawisk może być sygnałem, że zjawiska te wykraczają poza zakres teorii.

W przypadku, gdy następujące po sobie teorie łączy graniczna zbieżność równań, można powiedzieć, że poprzedniczka jest aproksymacyjnie prawdziwa w swoim zakresie i fałszywa poza nim. Teoria Newtona jest aproksymacyjnie prawdziwa w zakresie ruchów z małymi prędkościami i fałszywa poza tym zakresem. W przypadku przejścia od teorii Newtona do teorii Einsteina (STW) zmiana teorii łączy się ze zmianą zakresu teorii w taki sposób, że klasa zjawisk paradygmatycznych teorii Newtona jest granicznym przypadkiem teorii Einsteina i paradygmatyczne zastosowania teorii Einsteina leżą poza zakresem teorii Newtona.

Natomiast paradygmatyczne zjawiska teorii Fresnela i teorii światła Maxwella stanowią te same zjawiska optyczne. Teorie te mogą być 
albo zgodne odnośnie do poszczególnych kwestii, albo się wykluczać, nie mogą natomiast, w tym aspekcie, stanowić swojego dopełnienia.

T. Kuhn argumentuje, że jeśli chce się ratować teorie (np. mechanikę Newtona) przez ograniczenie zakresu ich stosowalności, to należałoby ograniczyć ten zakres „do tych zjawisk i do tego rzędu ścisłości, którym aktualnie dysponujemy. (...) uznać należałoby, że uczony nie może rościć sobie prawa, by mówić w sposób "naukowy« o jakimkolwiek zjawisku, którego dotąd nie obserwował" (Kuhn 2001, 180). Jednak paradygmatyczny sposób określania zasięgu teorii pozwala stosować ją do nowych zjawisk, o ile zostaną one zinterpretowane jako podobne do paradygmatycznych pod rozpatrywanym względem. To, czy taka interpretacja jest poprawna, jest rozstrzygane ostatecznie z perspektywy nowej teorii, która wskazuje teoretyczne ograniczenia zakresu poprzedniczki. Jednak pewne empiryczne przesłanki, że teoria jest stosowana do zjawisk, które wykraczają poza jej zakres, wynikają z braku sukcesu w wyjaśnianiu tych zjawisk. Na przykład mechanikę i optykę klasyczną stosowano do wyjaśnienia doświadczenia Michelsona-Morley’a, ale nie osiągnięto na tej drodze satysfakcjonującego sukcesu. Ograniczenia zakresu teorii pojawiają się zatem już na jej gruncie

Podsumowując, kiedy zachodzi przypadek, że równania poprzedniczki są granicznymi przypadkami następczyni, aproksymacyjna prawdziwość poprzedniczki $T_{1} \mathrm{w}$ świetle następczyni $\mathrm{T}_{2}$ oznacza „lokalną”, czyli ograniczoną do zjawisk granicznych, zgodność obu teorii. W tym wypadku aproksymacyjna prawdziwość ma charakter „lokalnej” prawdziwości, a nie, jak w wypadku zachowania równań w następczyni w niezmienionej postaci, charakter „częściowej” prawdziwości. Worrall ograniczał ciągłość teorii tylko do niezinterpretowanych równań matematycznych. Czy relacja korespondencji pozwala mówić jeszcze o innego rodzaju ciągłości pomiędzy teoriami i czy wykracza ona poza ciągłość równań i zachowanie własności detekcyjnych obserwowanych zjawisk? 


\section{RELACJA KORESPONDENCJI I CIĄGŁOŚĆ MIĘDZY NASTĘPUJĄCYMI PO SOBIE TEORIAMI}

Interpretacja relacji korespondencji jako przejawu pewnego rodzaju ciągłości pomiędzy teoriami, jak było wspomniane, jest kwestionowana $\mathrm{z}$ powodu niewspółmierności następujących po sobie teorii ${ }^{10}$. Według Kuhna niewspółmierne teorie się wykluczają ${ }^{11}$. Można pytać, jak graniczna zbieżność równań przekłada się na ciągłość innych elementów przy zmianie teorii? Co znaczy, że teoria Newtona jest aproksymacyjnie prawdziwa w świetle STW? Zgodnie z teorią Newtona czas jest absolutny, a masa ciał jest stała i nie zależy od ich prędkości, natomiast według STW czas jest względny, a masa ciał rośnie wraz z ich prędkością. Thomas Kuhn określa następujące po sobie teorie jako niewspółmierne, czyli takie, pomiędzy którymi nie zachodzi teoretyczna ciągłość. Dają one odmienne obrazy świata, których nie można uzgodnić. Ontologie takich teorii są całkowicie różne i nawet jeśli operują tymi samymi terminami, to sensy tych terminów są całkowicie odmienne (Kuhn 2001, 257-262). Kuhn przytacza na to wiele przykładów, jak choćby pojęcie „masa” w teorii Newtona i w teorii relatywistycznej, które mają inne sensy. Odnosząc się do dynamiki relatywistycznej Einsteina i dynamiki z Principiów Newtona, Kuhn twierdzi, że jeśli jedna z niewspółmiernych teorii jest prawdziwa, to druga musi być fałszywa. Według niego „teorię Einsteina można przyjąć, tylko uznając zarazem, że Newton nie miał racji” (Kuhn 2001, 177).

10 Szczegółowej analizy zagadnienia niewspółmierności teorii dostarcza np. K. Jodkowski (Jodkowski 1984). Tutaj jednak sam problem niewspółmierności nie będzie dyskutowany. Nie chodzi bowiem o porównywanie dwu teorii, lecz o pokazanie ich konsekwencji w obszarze zjawisk granicznych.

11 Wbrew temu, co twierdzi Kuhn, porównanie między niewspółmiernymi teoriami nie zawsze musi prowadzić do wykazania ich wzajemnej sprzeczności. Np. argument przeciw uznawaniu wzajemnej sprzeczności pomiędzy pojęciem masy w mechanice Newtona i STW przedstawia Ardnés Rivadulla (Rivadulla 2004, 417-429). 
Istotnie, obie teorie mogą być niewspółmierne i dostarczać ogólnie odmiennych obrazów zjawisk ruchu, tak jak ujmuje to Kuhn, jednak mogą one, wbrew twierdzeniu Kuhna, dawać w zakresie przypadków granicznych nie tylko zbliżone równania, ale też opisy, przewidywania i wyjaśnienia zjawisk. Teoria Newtona może dobrze przybliżać STW dla granicznych przypadków ruchu z małymi prędkościami. Choć zdania: „masa ciała $m$ jest stała” (jak wynika z teorii Newtona) oraz „masa ciała $m$ nie jest stała, lecz wzrasta wraz ze wzrostem prędkości ciała $\mathrm{v}$ zgodnie $\mathrm{z}$ równaniem $\mathrm{m}=\mathrm{m}_{0} /\left(1-\mathrm{v}^{2} / \mathrm{c}^{2}\right)^{1 / 2}$ " (zgodnie z STW) można traktować jako sprzeczne, to przy małych prędkościach v, gdy v $\mathrm{v}^{2} \mathrm{c}^{2}$ zdąża do 0 , obie zależności generują zbieżne równania, opisy i przyczynowe wyjaśnienia zjawisk mechanicznych, między którymi różnice są do pominięcia. Relatywistyczna zmiana masy przy małych prędkościach $\mathrm{v}$ jest do pominięcia ze względu na jej znikomo mały stosunek do całkowitej masy ciała. Nie będzie ona miała znaczącego wpływu na relacje ilościowe odzwierciedlające zjawiska tego zakresu i na ich przyczynowe wyjaśnianie. Podobnie ma się sprawa $\mathrm{z}$ innymi wielkościami relatywistycznymi w zakresie małych prędkości. W tych aspektach można powiedzieć, że teoria Newtona jest w zakresie ruchów klasycznych aproksymacyjnie prawdziwa, dobrze przybliża STW, zarówno jej równania, jak i dostarczane wyjaśnienia zjawisk. Efekty, które opisuje STW są zauważalne i znaczące dla ruchów ciał z prędkościami zbliżonymi do prędkości światła, przestają one natomiast odgrywać istotną rolę w przypadkach ruchów z małymi prędkościami. Efekty relatywistyczne dają przy małych prędkościach znikomy wkład do obserwowanych relacji przyczynowych. Nie tylko równania i liczbowe wyniki pomiarów, ale i przyczynowe wyjaśnienie zjawisk dostarczanych przez mechanikę relatywistyczną w granicy małych prędkości zbliża się do wyjaśnienia klasycznego.

Teoria Einsteina ogranicza aproksymacyjną prawdziwość teorii Newtona do klasy ruchów z małymi prędkościami. Nie unieważnia 
natomiast praw i wyjaśnień mechaniki klasycznej w takim sensie, w jakim rozwój nauki unieważnił hipotezę eteru.

Według Laudana relacja korespondencji nie gwarantuje ciągłości teoretycznej, gdyż „wiele teorii (nawet w »naukach dojrzałych«, jak fizyka) nie zachowuje sukcesu eksplanacyjnego swoich poprzedniczek w całości" (Laudan 2018, 57). Stephan Hartmann wskazuje, że relacja korespondencji może być bardzo różnorodna i przejawiać się jako odpowiedniość różnych elementów następujących po sobie teorii (Hartmann 2002, 79-94). W płaszczyźnie ontologicznej odpowiedniość między teoriami polega na tym, że niektóre albo wszystkie obiekty starej teorii są też obiektami nowej. Natomiast w płaszczyźnie epistemologicznej odpowiedniość może polegać na zbieżności jednego lub kilku elementów, takich jak terminy teorii, równania matematyczne, modele, wartości liczbowe obserwowanych wielkości itp. Każda zatem relacja korespondencji może być nieco inna i dlatego, jego zdaniem, nie należy poszukiwać jakiegoś zunifikowanego modelu zmiany teorii w nauce, gdyż każda zmiana teorii wymaga odmiennego uzasadnienia zachowania ciągłości teoretycznej. Nie wszystkie elementy dojrzałych teorii należy traktować jako posiadające swoje odpowiedniki w następczyniach. Wystarczy, aby niektóre elementy związane $\mathrm{z}$ sukcesem poprzedniczki wykazywały taką graniczną zbieżność. Mówimy wtedy o ciągłości w danym aspekcie.

Według Worralla tylko równania matematyczne zachowują ciągłość w nowej teorii (są zachowane w swojej pierwotnej formie lub są granicznymi przypadkami równań nowej teorii). Interpretacja ontologiczna równań zmienia się natomiast od teorii do teorii i nie przejawia ciągłości. Stanowi to jednak znaczne ograniczenie realizmu w zakresie realności obiektów teoretycznych. Realne są tylko relacyjne zależności pomiędzy niepoznawalnymi obiektami, odzwierciedlane w równaniach. Chakravartty rozszerza realistyczną interpretację na niektóre własności obiektów teoretycznych. Są to ich własności detekcyjne odzwierciedlane w równaniach teorii. Obiekty charakteryzowane przez te własności są realne i są zachowane w kolejnych 
teoriach. Tak jest w wypadku zachowania części teorii Fresnela. Jest ona zachowana $z$ jej empiryczną interpretacją (choć niekoniecznie ontologiczną).

Jeśli teorie pozostają do siebie w relacji korespondencji, to ich zakresy są różne w tym sensie, że zjawiska paradygmatyczne dla poprzedniczki stanowią graniczne przypadki zakresu następczyni. Obiekty i relacje, jakie leżą u podstaw struktury zjawisk, reprezentowanej $\mathrm{w}$ równaniach starej teorii, nie zawsze są tymi obiektami i relacjami, które wyznaczają struktury reprezentowane przez równania nowej teorii. Wystarczy jednak, aby odpowiednie obiekty nowej teorii, które moga przyjmować graniczne wartości określonych parametrów, miały dla tych parametrów własności zbieżne $\mathrm{z}$ własnościami obiektów poprzedniczki ${ }^{12}$.

Chakravartty wykazuje, że za relacje, które wyznaczają struktury (o których mówi Worrall), odpowiadają własności detekcyjne obiektów tworzących te struktury. Wyjaśnienie tych własności odwołuje się do wewnętrznej struktury owych obiektów, czyli elementów wewnętrznych i relacji między nimi. Te elementy i relacje charakteryzują już inne zjawiska i są reprezentowane przez równania innej (nowej) teorii. Powstaje w ten sposób hierarchiczny układ struktur przyczynowych zjawisk powiązany ze sposobem wyjaśniania własności obiektów przez ich strukturę wewnętrzną. Własności zewnętrzne obiektów i tworzone przez nie relacje, reprezentowane $w$ równaniach teorii $\mathrm{T}_{1}$, są wyjaśniane przez ich wewnętrzne struktury i związane z nimi zjawiska niższego poziomu, które są przedmiotem teorii $\mathrm{T}_{2}$. Np. własności ciał makroskopowych wyjaśniane są przez ich strukturę

12 W jednym z podręczników fizyki autor tak pisze na temat zasady korespondencji: „Jest rzeczą oczywistą, że mechanika kwantowa jest teorią ogólniejszą od mechaniki klasycznej. W granicy, gdy obserwujemy coraz większe układy i zakłócenia spowodowane obserwacjami mogą być pominięte, mechanika kwantowa przechodzi w mechanikę klasyczną" (Matthews 1974, 37). Tu jednak nie mówimy o zasadzie korespondencji, a jedynie o relacji korespondencji. 
atomową. Własności atomów wyjaśniane są przez własności ich wewnętrznych składników itd.

Paradygmatyczne zjawiska kolejnych dojrzałych teorii, na przykład teorii klasycznej i kwantowej, są charakterystyczne dla różnych poziomów tej hierarchii, podobnie jak do różnych poziomów tej hierarchii należą charakterystyczne dla obu teorii obiekty. Nowsza teoria jako bardziej fundamentalna obejmuje swoim zakresem także zjawiska i obiekty graniczne, będące paradygmatycznymi przypadkami poprzedniczki, jednak typowe dla nowszej teorii efekty nie odgrywają dla tych granicznych przypadków znaczącej roli. Na przykład ważna na poziomie kwantowym nieokreśloność jednoczesnego położenia i pędu ciała nie powoduje obserwowalnych zmian ani teoretycznych (obliczeniowych) różnic w opisach ruchu planet czy nawet piłeczek tenisowych. Jednak staje się ważna dla opisu oddziaływań na poziomie kwantowym. Obiekty klasyczne spełniają graniczne warunki teorii kwantowej, choć nie są paradygmatyczne dla teorii kwantowej. Natomiast paradygmatyczne obiekty teorii kwantowej mają całkowicie inne, nowe własności w stosunku do postulowanych przez teorię klasyczną.

Ciągłość pomiędzy takimi teoriami nie oznacza, że obiekty zastępowanej teorii zostają zachowane w nowej jako jej obiekty paradygmatyczne. Raczej polega na tym, że własności charakteryzujące paradygmatyczne obiekty nowej teorii nie odgrywają w zakresie zjawisk granicznych znacznej roli. Natomiast paradygmatyczne obiekty poprzedniczki zostają zachowane jako obiekty właściwe dla zjawisk granicznych. Np. teoria kwantowa postuluje inne obiekty niż planety czy piłeczki tenisowe, choć ich nie wyklucza, lecz zachowuje jako obiekty graniczne, których własności kwantowe nie ujawniają się w sposób istotny w zjawiskach makroskopowych.

Wymaganie, aby aproksymacyjnie prawdziwe elementy poprzedniczki zostały zachowane w nowej teorii, jest zbyt silne zarówno w stosunku do równań, jak i obiektów teorii w przypadku relacji korespondencji pomiędzy teoriami. Jest to równoważne wymaganiu, 
aby zjawiska wszystkich skal i poziomów miały taką samą strukturę, którą ujmuje jedna dla wszystkich zakresów zjawisk teoria. Jeśli uwzględni się „lokalność” teorii naukowych, otrzymuje się inne rozumienie ciągłości obiektów w wypadku zmiany teorii. Można mówić o zachowaniu obiektów przy zmianie teorii, gdy obiekty starej teorii znajdują swoją identyfikację jako graniczne przypadki równań nowej, bardziej uniwersalnej teorii. W tym sensie nowa teoria zachowuje obiekty poprzedniczki, bez ograniczania ich jedynie do własności detekcyjnych. Rozwinięcie tego problemu wykracza poza podjęte tu rozważania.

Laudan twierdzi, iż „uogólnienie, że serie następujących po sobie teorii w rozwiniętych naukach wykazują relacje o charakterze przypadków granicznych, jest ewidentnie fałszywe" (Laudan 2018, 57). Wskazane przez niego przypadki takie, jak np. przejście od teorii Fresnela do teorii Maxwella, faktycznie zachowują inny rodzaj relacji pomiędzy teoriami niż relacja korespondencji, co było już omówione wyżej. W ich przypadku argument PI jest uchylany zgodnie ze strategią divide et impera. Ciągłość teorii wymaga w takim wypadku, aby pewne elementy teorii (np. równania lub obiekty) stały się elementami następczyni.

Podsumowując ostatnie rozważania, można powiedzieć, że inaczej ciągłość teorii przejawia się w przypadku, gdy teorie łączy relacja korespondencji. Równania teorii nie są zachowane w następczyni, a jedynie są granicznymi przypadkami jej równań. Zbieżność równań pociąga jednak za sobą zbieżność przewidywania liczbowych wyników pomiarów i przyczynowego wyjaśnienie zjawisk w zakresie przypadków granicznych.

Zastosowanie tych samych kryteriów ciągłości poszczególnych elementów teorii dla obu wyróżnionych schematów zmiany teorii prowadzi do nadmiernego zawężenia realizmu, wynikającego $\mathrm{z}$ narzucenia kryteriów strategii divide et impera dla wszystkich przypadków zmiany teorii. Pokazano, że gdy teorie łączy relacja korespondencji, pojawienie się nowej teorii nie oznacza, że jej poprzedniczka jest 
fałszywa w zakresie zjawisk granicznych, ale że jest aproksymacyjnie prawdziwa w swoim zakresie zastosowania.

Dotyczy to nie tylko jej równań, ale i dostarczanych wyjaśnień zjawisk w tym zakresie oraz niektórych zobowiązań ontologicznych. Jak już wspomniano, każdy przypadek zmiany teorii wymaga odrębnego opracowania w szczegółach. Jednak pokazanie różnorodności w schematach zmiany teorii i związanej z tym szerszej możliwości realistycznej interpretacji zmiany teorii wbrew zarzutowi PI stanowi wzmocnienie argumentacji na rzecz realizmu naukowego.

\section{ZAKOŃCZENIE}

Oś powyższych rozważań stanowiło pytanie o możliwość uzgodnienia realizmu naukowego z argumentem PI. Szczególnie ważne z tej perspektywy jest uzasadnienie, że sukces teorii związany jest $\mathrm{z}$ jej aproksymacyjną prawdziwością. Linia obrony realizmu naukowego, wyznaczona przez realizm strukturalny i semirealizm, kładzie nacisk na zachowanie związanych z sukcesem elementów teorii w jej następczyni. Przyjmowany sposób wyjaśnienia takich przypadków, zgodnie ze strategią divide et impera, uchyla częściowo trudności wynikające ze zmiany teorii dla przypadku, gdy nowsza teoria zachowuje część swojej poprzedniczki związaną z jej sukcesem. Sukces teorii jest wyznacznikiem jej aproksymacyjnej prawdziwości, która jest rozumiana w sensie prawdziwości części teorii. Argumenty Worralla odwołują się bezpośrednio do przejścia od optyki Fresnela do teorii elektromagnetycznej światła, będącego wzorcowym przykładem zmiany teorii najczęściej analizowanym w tym kontekście.

Pokazano, że ten unikatowy przypadek zmiany teorii różni się pod wieloma istotnymi względami od zachodzących częściej przypadków zmiany teorii, dla których następujące po sobie teorie pozostają w relacji korespondencji. Worrall wskazuje te dwa schematy zmiany teorii, nie wyprowadza jednak z relacji korespondencji żadnych dodatkowych argumentów dla szerzej rozumianego realizmu naukowego. 
Uznaje, że relacja korespondencji dowodzi jedynie słuszności realizmu strukturalnego i kwestionuje łączenie $\mathrm{z}$ tą relacją argumentów na rzecz innego rodzaju ciągłości między następującymi po sobie teoriami niż ciągłość równań. Prowadzi to do znacznego ograniczenia stanowiska realistycznego.

Przeprowadzone w artykule rozważania pozwoliły wskazać, że oba te schematy, odwołujące się do innej relacji pomiędzy następującymi po sobie teoriami, dostarczają innego rozumienia aproksymacyjnej prawdziwości zastępowanej teorii i innych podstaw dla ciągłości teoretycznej. W przypadku, gdy zostaje zachowana część teorii, ciągłość między następującymi po sobie teoriami polega na zachowaniu elementów poprzedniczki jako spójnej części następczyni, obowiązującej w całym jej zakresie, a nie tylko dla zjawisk granicznych. Aproksymacyjna prawdziwość poprzedniczki polega na „częściowej” prawdziwości, czyli prawdziwości części teorii zachowanej w następczyni. Rozwój wiedzy przez zamianę teorii polega w tym przypadku na kumulacji aproksymacyjnie prawdziwych elementów, podczas gdy części fałszywe są z czasem eliminowane w kolejnych teoriach.

W przypadku relacji korespondencji odwołanie się do zależności pomiędzy zakresami następujących po sobie teorii i ich lokalnego charakteru pozwoliło inaczej rozumieć aproksymacyjną prawdziwość teorii i ciągłość między teoriami. Aproksymacyjna prawdziwość teorii polega w tym przypadku na przybliżonej zgodności równań, przewidywań i wyjaśnień właściwych dla każdej z teorii. Nowa teoria zachowuje te $\dot{z}$ „lokalnie” obiekty poprzedniczki w sensie, jaki został omówiony wcześniej. Pokazano, że niewspółmierność teorii nie podważa takiej „lokalnej” ciągłości. Kumulacja wiedzy w takim przypadku polega na tym, że z perspektywy nowszej, bardziej uniwersalnej teorii jej poprzedniczka może być ujmowana jako aproksymacyjnie prawdziwa dla przypadków granicznych. Poza tymi granicznymi przypadkami jest fałszywa.

Rozwój wiedzy polega w tym schemacie na formułowaniu coraz bardziej uniwersalnych teorii, obejmujących coraz szerszy zakres 
zjawisk. Sukces predykcyjny dojrzałych teorii zastąpionych nowymi dotyczył przewidywania zjawisk z ich zakresu i do tego zakresu ogranicza się ich aproksymacyjna prawdziwość. Pomimo zasadniczej odmienności nowej teorii, dostarczającej w stosunku do poprzedniczki nowych modeli matematycznych i nowej interpretacji ontologicznej dla zjawisk z nowego zakresu, można, ze względu na omówioną zgodność dla przypadków granicznych, interpretować zmianę teorii jako ciągły rozwój nauki prowadzący do wiedzy o coraz szerszym zakresie zjawisk.

$Z$ tej perspektywy argument Laudana, że dojrzałe teorie okazują się w wyniku zmiany teorii fałszywe, nie odzwierciedla poprawnie faktycznej sytuacji zmiany ważnych w fizyce teorii, gdy między teoriami zachodzi relacja korespondencji. Nie ujmuje on adekwatnie relacji pomiędzy następującymi po sobie teoriami i w konsekwencji nie podważa stanowiska realistycznego. Stanowisko realistyczne akceptuje fakt, iż bywają teorie fałszywe (w całości lub w części), natomiast fakt, że teorie, które odniosły sukces predykcyjny, były albo aproksymacyjnie prawdziwe w jakieś swej części, albo aproksymacyjnie prawdziwe w jakimś zakresie zjawisk, przemawia na korzyść realizmu.

$Z$ takiej perspektywy należy też rozumieć pytanie o prawdziwość naszych obecnych najlepszych teorii. Teorie, które ze względu na swoje wzajemne powiązania w wyjaśnianiu zjawisk, jak też na zakres sukcesu (predykcyjnego, empirycznego i eksplanacyjnego), spełniają kryteria dojrzałych teorii, moga być uznane za aproksymacyjnie prawdziwe w zakresie zjawisk, w jakim odnoszą ten sukces. Współczesna nauka potwierdza różnymi metodami empirycznymi realność obiektów postulowanych przez teorie i ostatecznie ich status ontologiczny jest łączony ze stopniem takiego potwierdzenia. W świetle dalszego rozwoju wiedzy zakres stosowalności naszych najlepszych teorii może jednak okazać się ograniczony w przypadku odkrycia nowych zjawisk spoza znanego obecnie zakresu. 
Relacja korespondencji, jak pokazano, przy uwzględnieniu „lokalnego" charakteru zastępowanych teorii, staje się dodatkowym argumentem na rzecz realistycznej interpretacji zmiany teorii w nauce, wyrażonym nie w kategoriach kumulacji elementów jednej teorii w drugiej, a w kategoriach ciągłego poszerzania zakresu zjawisk i dostarczania nowych modeli teoretycznych dla coraz szerszej klasy zjawisk, w których jednak poprzedniczki zostają zachowane we właściwym dla siebie zakresie zjawisk, stanowiących graniczne przypadki nowszych teorii.

\section{BIBLIOGRAFIA}

Becker Arenhart, J.R., Bueno, O. (2015). Structural realism and the nature of structure. European Journal for Philosophy of Science, 5, 111-139.

Boyd, R.N. (1983). On the Current Status of the Issue of Scientific Realism. Erkenntnis, 19(1-3), 45-90.

Buczkowska, J. (2020). Realizm naukowy wobec zmiany teorii w nauce. Studia Philosophiae Christianae, 56(3), 5-30.

Chakravartty, A. (1998). Semirealism. Studies in History and Philosophy of Science, 29(3), 391-408.

Da Costa, N., French, S. (1990). The Model-Theoretic Approach to the Philosophy of Science. Philosophy of Science, 57(2), 248-265.

Fraassen, B.C. van. (1980). The Scientific Image. Oxford: Oxford University Press. Fraassen, B.C. van. (1997). Structure and Perspective: Philosophical Perplexity and Paradox. W: M.L. Dalla Chiara (red.), Logic and Scientific Methods. Vol. 1, 511-530. Dordrecht: Kluwer.

Frigg, R. (2006). Scientific Representation and the Semantic View of Theories. Theoria, 21(1), 49-65.

Giere, R. (1988). Explaining Science: A Cognitive Approach. Chicago: Chicago University Press.

Giere, R. (2004). How Models Are Used to Represent Reality. Philosophy of Science, 71(5), 742-752.

Grobler, A. (2008). Metodologia nauk. Kraków: Wydawnictwo Aureus - Wydawnictwo Znak.

Hartmann, S. (2002). Essay review: On correspondence. Studies in History and Philosophy of Modern Physics, 33, 79-94. 
Jodkowski, K. (1984). Teza o nierwspótmierności w ujęciu Thomasa Kubna i Paula Feyerabenda. Lublin: Wydawnictwo UMCS.

Kotowski, M. (2014). O rozwoju realizmu naukowego jako selektywnego sceptycyzmu. Filozofia Nauki, 22(3), 105-123.

Kuhn, T.S. (2001). Struktura rewolucji naukowych. Warszawa: Fundacja Aletheia. Laudan, L. (2018). Obalenie realizmu konwergentnego. W: M. Kotowski (red.), Spór o realizm naukowy, 29-65. Wrocław: Oficyna Naukowa PFF.

Lyons, T.D. (2006). Scientific Realism and the Stratagema de Divide et Impera. The British Journal of the Philosophy of Science, 57(3), 537-560.

Matthews, P.T. (1974). Wstęp do mechaniki kwantowej. Warszawa: PWN.

Park, S. (2017). On Treating Past and Present Scientific Theories Differently. Kriterion, 31(1), 63-76.

Psillos, S. (1999). Scientific Realism: How Science Tracks Truth. London: Routledge. Putnam, H. (1975). What is Mathematical Truth?. W: Mathematics, Matter and Method, Collected Papers, Vol. 2, 60-78. Cambridge: Cambridge University Press.

Rivadulla, A. (2004). The Newtonian Limit of Relativity Theory and the Rationality of Theory Change. Synthese, 141(3), 417-429.

Rodzeń, J. (2006). Kilka uwag o tzw. pesymistycznej meta-indukcji. Filozofia Nauki, 55(3), 97-110.

Suppe, F. (1989). The Semantic Conception of Theories and Scientific Realism. Chicago: University of Illinois Press.

Vickers, P. (2017). Understanding the Selective Realist Defence Against the PMI. Synthese, 194(9), 3221-3232.

Worrall, J. (2018). Realizm strukturalny. To co najlepsze z dwóch światów. W: M. Kotowski (red.), Spór o realizm naukowy, 145-175. Wrocław: Oficyna Naukowa PFF.

\section{THE RELATIONSHIPS BETWEEN SUCCESSIVE THEORIES AND WAYS OF RESPONDING TO THE PESSIMISTIC INDUCTION ARGUMENT}

\footnotetext{
Abstract. This paper considers and aims to advance the discussion on the reconciliation of scientific realism with the pessimistic induction argument. It presents a novel argument in favour of scientific realism based on the correspondence relationship between successive theories, which has been overlooked in the debates on structural realism and semirealism. Firstly, the paper argues that the traditional arguments for scientific realism , based on the divide et impera strategy, correctly refer to cases of theory change similar to the replacement of Fresnel's optical theory with the electromagnetic theory of light. However, it is argued that such arguments do not apply to cases of theory change in which successive theories remain in a correspondence relation. Worrall's solution does not take into account the important implications that follow from this relation for an understanding of theoretical
} 
continuity despite theory change. Taking into account the different scope of phenomena in successive theories, linked by a correspondence relationship, enables us to indicate a different type of continuity between theories and to formulate additional justification for a realist position concerning this type of theory change. Secondly, it is argued that a correspondence relationship between successive theories admits an understanding of approximate truthfulness and the continuity between theories different from the divide et impera strategy. By appealing to the limited scope of the theory that is replaced and its "local" correctness according to its successor, it is possible to avoid some of the objections raised against the traditional arguments in favour of scientific realism based on the correspondence relationship. In the light of this justification, the thesis that successful mature theories turn out to be false as a result of theory change does not apply to cases of theory change in which successive theories are linked by a correspondence relation. Our argument overrules PI's objection to this kind of theory change and does not impose limitations on scientific realism resulting from structural realism.

Keywords: scientific realism; structural realism; theory change in science; approximate truthfulness; theoretical continuity

\section{JANINA BUCZKOWSKA}

Uniwersytet Kardynała Stefana Wyszyńskiego w Warszawie, Instytut Filozofii (Cardinal Stefan Wyszyński University in Warsaw, Institute of Philosophy, Poland) ORCID https://orcid.org/0000-0001-5387-2310 janina.buczkowska@uksw.edu.pl

DOI 10.21697/spch.2021.57.A.07 ${ }_{\text {OPEN }} \partial_{\text {aCCESS }}$ (c) $\underset{\mathrm{BY}}{\Theta} \Theta_{\mathrm{ND}}$ Tekst jest udostępniany na zasadach licencji Creative Commons (CC BY-ND 4.0 Międzynarodowe). Zgłoszono: 24/03/2021. Zrecenzowano: 18/06/2021. Zaakceptowano do publikacji: 05/07/2021. 